\title{
Volatile constituents and oxidative stability of virgin olive oils: influence of the kneading of olive-paste
}

\author{
By G. Lercker ${ }^{1 *}$, N. Frega ${ }^{2}$, F. Bocci ${ }^{3}$ and M. Mozzon ${ }^{2}$ \\ 1 Istituto di Industrie Agrarie, Universitá degli Studi di Bologna, Via S. Giacomo, 7. \\ 401216 Bologna, Italy. e-mail: lercker@biblio.cib.unibo.it \\ 2 Dip. di Biotecnologie Agrarie ed Ambientali, Universitá degli Studi di Ancona, Via Brecce Bianche, \\ 60131 Ancona, Italy. \\ 3 D.I.S.T.A.M., Sez. di Industrie e Tecnologie Alimentari, Universitá degli Studi di Firenze, \\ Via Donizetti, 6. 50144 Firenze, Italy.
}

\section{RESUMEN}

Constituyentes volátiles y estabilidad oxidativa de aceites vírgenes de oliva: influencia del batido de la pasta de aceitunas.

La molienda de aceitunas, el batido de la pasta y la separación del aceite de oliva producen una serie de transformaciones en las características del aceite que posteriormente será extraído. Es sabido que la formación de distintos componentes del aroma del aceite derivan de reacciones oxidativas enzimáticas. El contacto entre el aceite y la pasta de aceitunas incrementa la lipolisis y la oxidación lipídica, debido a un incremento de la actividad de las lipasas presentes en la pasta y a una acción lipoxigenásica respectivamente. La elección de los parámetros tecnológicos está en relación directa con la futura estabilidad y las características organolépticas del aceite. En este trabajo se confirma la formación de tales compuestos evidenciándose la degradación oxidativa del aceite en relación al tiempo de batido empleado. Se demuestra también una pérdida de antioxidantes (componentes polares menores) por efectos oxidativos en modo proporcional al tiempo de batido.

PALABRAS-CLAVE: Aceite de oliva virgen - Aceituna - Batido de la pasta - Estabilidad oxidativa - Molienda - Separación aceite - pasta de aceituna.

\section{SUMMARY}

Volatile constituents and oxidative stability of virgin olive oils: influence of the kneading of olive-paste.

Olive crushing, olive-paste kneading and separation of the oil are the most important technological steps in olive oil production since they directly influence the future quality of the product. The contact between the oil and the olive-paste increases lipolysis and lipid oxidation, which are mainly due to the highly-active lipases present in the paste and the lipoxygenase action, respectively. The choice of the technological parameters is directly related to the oil future stability and its organoleptic characteristics. This study confirms and emphasizes the fact that the oxidative degradation, simultaneously with the well-known formation of the flavor compounds, is related to the time required for the separation of the oil-water emulsion. Loss of the natural antioxidants (minor polar components) by an oxidative effect was demonstrated to be also influenced by the time required for oil separation.

KEY-WORDS: Crushing - Oil-olive paste separation - Olive - Oxidative stability - Paste kneading - Virgin olive oil.

\section{INTRODUCTION}

Virgin olive oils extracted with gentle physical procedures show unique organoleptic and nutritional properties as compared to those of other vegetable oils. The extraordinary aroma of virgin olive oils is influenced by several production and processing parameters (Montedoro et al., 1986), such as the agronomic choices, olive cultivar, ripening degree and sanitary quality of olives, harvest system, post-harvest storage of fruits, processing technology and oil bottling and storage. Among these parameters, processing technology seems to greatly determine the final quality of the oil. It is well known that the organoleptic properties of virgin olive oils are significantly affected by the crushing method, the kneading process of the olive-paste, and the separation systems of crude oil or oil-water mixture from the olive-paste. All researchers and processing plant operators have underlined the negative effect of high temperatures and long processing time on the organoleptic quality of the oil (Montedoro et al., 1994).

On the other hand, the mechanisms of formation of some volatile constituents of olive oil aroma have recently been reported (Olias et al., 1993; Di Giovacchino et al., 1996). The biochemical lipoperoxidation generated 13-hydroperoxides from linoleic and linolenic acids, which decompose into a series of aliphatic C-6 volatile compounds following other enzymic patterns. These volatile compounds are actually secondary products, i.e. they are formed as a result of disruption of cell structure.

In the present work, the interaction between olive-paste kneading, oxidative stability and aroma constituents of virgin olive oils is investigated.

\section{EXPERIMENTAL}

Five $\mathrm{Kg}$ of olives from Frantoio and Moraiolo cultivars were ground together by a metal crusher 
(«fixed hammer» type), during $14 \mathrm{~min}$, and then olive-paste was subjected to a kneading process at $21^{\circ} \mathrm{C}$ for different time periods $(20,40,60$ and 70 min). After centrifugation, the oils obtained were passed through $0,45-\mu \mathrm{m}$ membrane filters.

Free acidity and peroxide value were determined according to the "Official Methods of Analysis» for fatty substances (NGD C-10, 1976; NGD C-35, 1976). The accelerated oxidation rates were plotted with a Rancimat mod. 679 (Metrohom AG, Herisau, Switzerland) at $110^{\circ} \mathrm{C}$; the rate of air flow through the samples was set to $20 \mathrm{~L} / \mathrm{h}$; the volatile reaction products were caught into measured vessels containing $60 \mathrm{~mL}$ of distilled water.

Volatile components were determined after collection by a charcoal cartridge absorption and directly injection into capillary gas chromatograph apparatus equipped with a MW-1 Microwave Sampler (J. Rektorik, Geneva, Switzerland) as injector, and a capillary polar column $30 \mathrm{~m} \times 0.3 \mathrm{~mm}$ i.d., $1 \mu \mathrm{m}$ of film thickness (Restek Stabilwax, Stepbio, Bologna, Italy) (Bocci et al., 1992; 1994).

For the minor polar components (MPCs) extraction, $10 \mathrm{~g}$ of each oil were homogenized with $10 \mathrm{~mL}$ of a methanol/water mixture $(80: 20, \mathrm{v} / \mathrm{v})$ for 1 min, using an Ultra-Turrax (Janke \& Kunkel, Ika Labortechnik, Staufen, Germany) at the lowest homogenization speed. After centrifugation, the methanol solution was separated and the extraction was repeated twice. The three methanol extracts were combined and vigorously washed with $50 \mathrm{~mL}$ of n-hexane. This mixture was again centrifuged and then the hydro-alcoholic layer was evaporated to dryness with a rotary evaporator at $50^{\circ} \mathrm{C}$, using anhydrous methanol for water elimination. The residue was redissolved in $10 \mathrm{~mL}$ of methanol and the solution obtained was divided into two like portions. The first one was transferred into the reaction vessel of Rancimat and evaporated to dryness with nitrogen flow, whereas the second one was analyzed by reversed phase-HPLC (RP-HPLC) and capillary gas chromatography (CGC) after silanization (Sweeley et al., 1963).

RP-HPLC analysis was carried out by a Varian Star 9010 (Valnut Creek, CA) equipped with a Spherex 3 ODS column (150 x $4.6 \mathrm{~mm}$ ) (Phenomenex, Torrance, CA) and a Polychrom 9065 diode-array detector set at $278 \mathrm{~nm}$. The solvent elution program is reported in Table I.

CGC analysis of trimethylsilyl ethers (TMS) of MPCs extracted from the oils was carried out with a Carlo Erba (Milano, Italy) HRGC mod. Mega 5160 equipped with a flame ionization detector (FID) and a fused silica capillary column (25 $\mathrm{m} \times 0.32 \mathrm{~mm}$ i.d.) coated with SE 52 (0.1-0.15 $\mu \mathrm{m}$ film thickness) (Supelco, Bellefonte, CA). Oven temperature was kept at $50^{\circ} \mathrm{C}$ for $1 \mathrm{~min}$, then programmed from $50^{\circ} \mathrm{C}$ to $300^{\circ} \mathrm{C}$ at $3^{\circ} \mathrm{C} / \mathrm{min}$ and maintained at this final temperature for $10 \mathrm{~min}$.
Table I

Elution program for the RP-HPLC analysis of minor polar components (MPCs)

\begin{tabular}{ccc}
\hline $\begin{array}{c}\text { Time } \\
(\mathrm{min})\end{array}$ & $\begin{array}{c}\text { Acetic Acid } \\
(\mathbf{2 \%} \text { in water }) \\
(\%)\end{array}$ & $\begin{array}{c}\text { Methanol } \\
(\%)\end{array}$ \\
\hline 0 & 95 & 5 \\
2 & 95 & 5 \\
18 & 75 & 25 \\
28 & 60 & 40 \\
40 & 0 & 100 \\
50 & 0 & 100 \\
\hline
\end{tabular}

\section{RESULTS AND DISCUSSION}

Table II reports the main volatile aldehides \% (with respect to total volatile constituents) of the virgin olive oil at different kneading times. As it was observed the volatile fraction contains about $20 \%$ of trans-2-hexenal at the end of olive crushing (time 0), which reaches a level of $50 \%$ after 70 min of kneading. Hexanal content, during the same period, doubles too, but it is significantly lower than trans-2-hexenal. These experimental data are in agreement with the specificities of the enzymes involved in biogenesis of virgin olive oil volatile constituents (Scheme of Figure 1) (Olias et al., 1993; Di Giovacchino et al., 1996): kneading gives rise to higher amounts of trans-2-hexenal as compared to hexanal, being the opposite of what is usually observed for their corresponding precursors (linolenic and linoleic acids, respectively).

The trans-2-hexenal formation could be useful for the organoleptic characterization of virgin olive oils («green» odor note) (Olias et al., 1993; Di Giovacchino et al., 1996); however, it should be pointed out that an intense lipoperoxidase activity enhances the amounts of primary autoxidation products (hydroperoxides). This means that this enzymic process not only generates some important aroma volatile components, but that it is also responsible for the future shelf-life of the virgin olive oil.

Table II

Volatile aldehides content at different kneading times

\begin{tabular}{ccc}
\hline $\begin{array}{c}\text { Kneading Time } \\
\text { (min) }\end{array}$ & $\begin{array}{c}\text { Hexanal } \\
\text { (\% of total } \\
\text { constituents) }\end{array}$ & $\begin{array}{c}\text { trans-2-hexenal } \\
\text { (\% of total volatile } \\
\text { constituents) }\end{array}$ \\
\hline 0 & 4,0 & 19,3 \\
20 & 4,8 & 46,7 \\
40 & 5,8 & 51,6 \\
70 & 7,1 & 45,2 \\
\hline
\end{tabular}




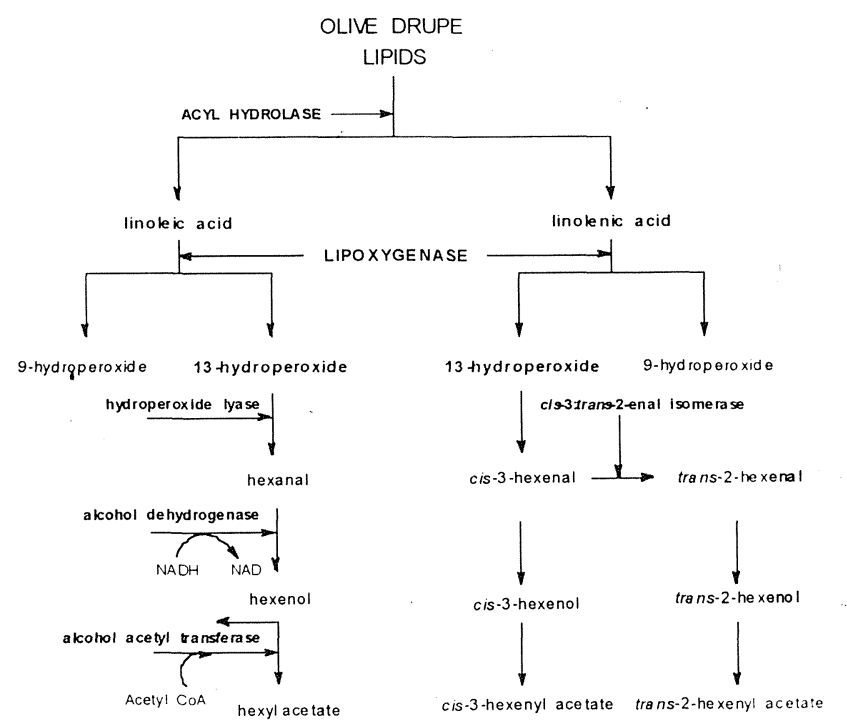

Figure 1

Formation pathways of some aroma components of virgin olive oils (Olias et al., 1993; Di Giovacchino et al., 1996)

At the end of kneading, the contact between the oil and the olive-paste is interrupted. From this point onwards, the amount of trans-2-hexenal present in the oily-phase slowly diminishes due to both a diffusion and a redox mechanisms. Under these conditions, chemical oxidation reactions are responsible of any changes of composition as progressive decrease of trans-2-hexenal and increase of hexanal. This hexanal rise can drastically modify the organoleptic profile of the oil which, in extreme deterioration conditions, can present a rancidity odor.

Conventional olive processing plants usually produce oils having a normal or a particularly intense olive oil odor, except for those situations in which one or more processing parameters are greatly modified. In this case, the resulting shelf life of the virgin olive oil is directly conditioned by these processing variations.

Rancimat stability test of the oils extracted from the olive-paste at different kneading times evidence a progressive reduced «induction period» (Figure 2). Peroxide value, (PV) not significantly vary (Table III) during kneading, probably due to the peroxide oxidative action against other oil components, such as MPCs with antioxidant activity (i.e. polyphenols). This assumption agrees, in fact, with the RP-HPLC (Montedoro et al., 1993; Angerosa and Di Giacinto, 1995; Evangelisti et al., 1997) (Figure 3) and CGC (Figure 4) profiles of the MPCs extracted from the virgin olive oils obtained by centrifugation of the olive-paste/oil during the kneading test.

Figure 5 shows the Rancimat traces of a refined seed oil added with the MPCs extracted from the virgin olive oils obtained from the kneading test. These results reflect a reduction of the natural antioxidant contents during kneading, due to enzymic peroxidation. In fact, the Rancimat time is related to the kneading time of olive-paste.

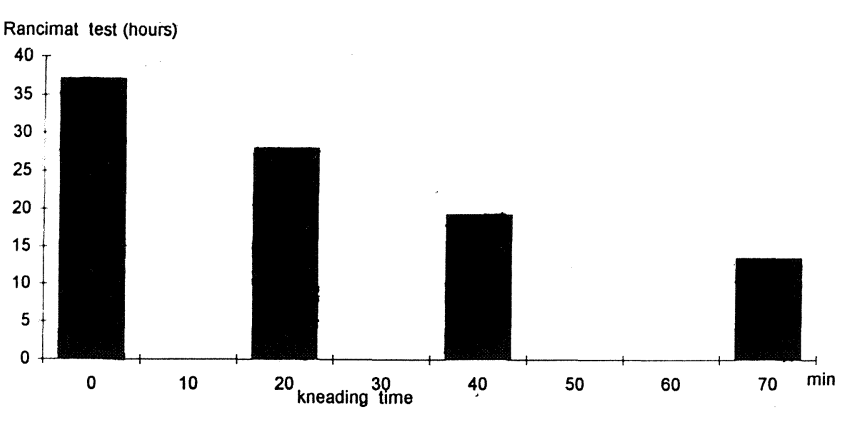

Figure 2

Oxidative behaviour of virgin olive oils obtained from olive-paste at different times $(0,20,40,70 \mathrm{~min})$ during the kneading process, evaluated by Rancimat test

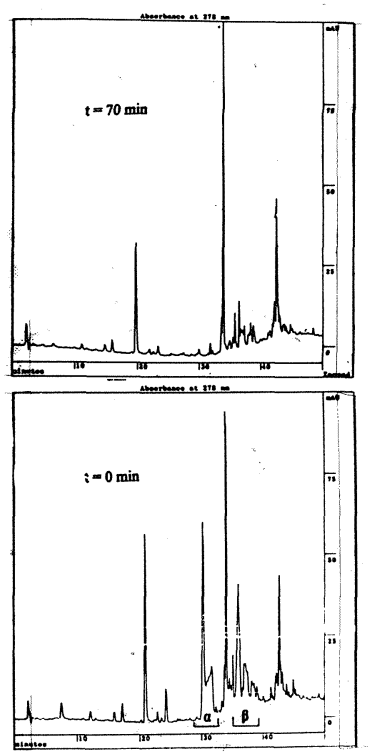

Figure 3

High performance liquid chromatographic trace of «minor polar compounds" extracted from virgin olive oils at different times during the kneading process $(0 \mathrm{~min}$ and $70 \mathrm{~min}$ ). Identification of part of peaks was reported by Montedoro et al., (1993), Angerosa and Di Giacinto (1995) and Evangelisti et al., (1997)

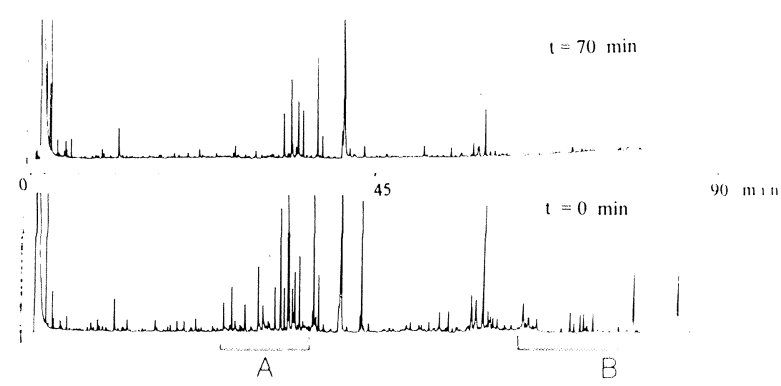

Figure 4

Capillary gas chromatographic trace of «minor polar compounds" (as trimethylsilyl derivatives) extracted from virgin oilve oils at different times during the kneading process $(0 \mathrm{~min}$ and $70 \mathrm{~min})$. Peak identification is in progress 


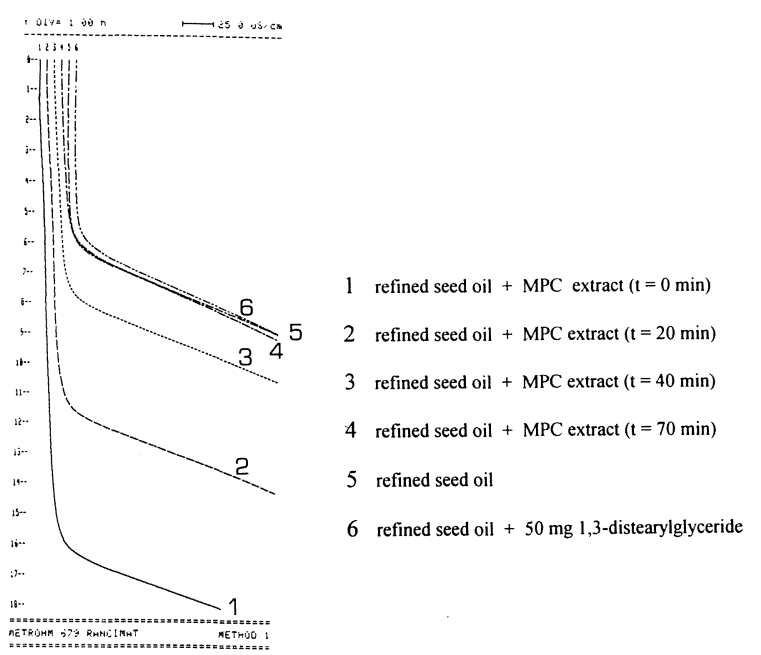

Figure 5

Rancimat test traces $\left(110^{\circ} \mathrm{C}\right)$ of refined seed oil added with "minor polar compounds" extracted from virgin olive oils obtained from olive-paste at different times during the kneading process

Table III also reports the acid values of the same oils subjected to different kneading times, which do not significantly vary.

Olive-paste kneading is an important step of olive processing, since it influences the future quality of the product and produces good oil extraction yields. Considering this economical parameter, the operators tend to increase kneading time which, on one hand, leads to a higher production of volatile aroma components and a pleasant taste formation but, on the other hand, reduces oil shelf-life.

Slow crushing of the olives by using a stone crusher also exhibits a simultaneous kneading action on the olive-paste. This type of process, however, operates a gentle olive crushing with shorter kneading times. This reduction of the processing time is mainly due to the absence of oil-water emulsions, thus producing a satisfactory yield of an oil with good sensory quality and a relative high shelf-life.

Table III

Free acid and peroxide values of oils obtained at different kneading times

\begin{tabular}{ccc}
\hline $\begin{array}{c}\text { Kneading Time } \\
\text { (min) }\end{array}$ & $\begin{array}{c}\text { Free Acids } \\
\text { (as oleic acid) }\end{array}$ & $\begin{array}{c}\text { Peroxide Value } \\
\text { (meq 0 } / \mathrm{Kg} \text { ) }\end{array}$ \\
\hline 0 & $0.46 \%$ & 11.9 \\
20 & $0.35 \%$ & 11.0 \\
40 & $0.39 \%$ & 11.0 \\
70 & $0.46 \%$ & 12.1 \\
\hline
\end{tabular}

Kneading temperature also plays an important role on the characteristics of olive oil. Higher temperatures accelerate all chemical, biochemical and physical-chemical interactions. In fact, lipid peroxidation, aroma generation and oil/olive-paste separation are faster at high temperatures but the shelf life of the final product is jeopardized (Montedoro et al., 1994).
Considering all these facts, the choice of the processing plant and the technological parameters for virgin olive oil production must take into account that the olive-paste/oil contact is a determinant factor for the characteristics of the final product.

The results reported in this study evidence that, in order to compare different processing plants, a previous "normalization" of at least one parameter of the virgin olive oil, such as the qualitative and quantitative polyphenol contents or the aroma characteristics, would be necessary. Up to now, the different technologies from the several commercial plants have, in fact, been misinterpreted because the tests have been performed without knowing how the single experimental conditions could affect the final quality of the oil.

\section{BIBLIOGRAPHY}

Angerosa, F. and Di Giacinto, L. (1995).- «Caratteristiche di qualità dell'olio vergine in relazione ai metodi di frangitura. Nota II».--Riv. Ital. Sostanze Grasse. 72, 1-4.

Bocci, F., Frega, N. and Lercker, G. (1992).-«Studio preliminare sui componenti volatili di oli di oliva extravergini».-Riv. Ital Sost. Grasse. 69, 611-613.

Bocci, F., Frega, N. and Lercker, G. (1994)._- «roposta di un metodo per la determinazione del benzene negli oli».-Riv. Ital. Sostanze Grasse. 71, 565-566.

Di Giovacchino, L., Angerosa, F. and Di Giacinto, L (1996)._- «ffect of mixing leaves with olives on organoleptic quality of oil obtained by centrifugation».J. Am. Oil Chem. Soc. 73, 371-374.

Evangelisti, F. Zunin, P. Tiscornia, E., Petacchi, R., Drava, G. and Lanteri, S. (1987).-«Stability to oxidation of virgin olive oils as related to olive conditions: study of polar compounds by chemiometric methods".-J. Am. Oil Chem. Soc. 74, 1017-1023.

Frega, N., Mozzon, M., Servidio, G. and Lercker, G. (1995).- — «Studio della resistenza all'ossidazione forzata degli oli extra vergini mediante Rancimat Test».-Riv. Ital. Sostanze Grasse. 72, 493-496.

Olias, J.M., Pérez, A.G., Rios, J.J. and Sanz, L.C. (1993).- "Aroma of virgin olive oil: biogenesis of the «green" odor notes».-J. Agric. Food Chem. 41, 2368-2373.

Montedoro, G.F., Garofalo, L. and Bertuccioli, M. (1986)."Gli oli extra vergini tipici: quali prospettive?».Industrie Alimentari. 25, 549-553.

Montedoro G.F., Servili, M. and Baldioli, M. (1994).— «Stato di dispersione colloidale delle paste di oliva e le implicazion sulle caratteristiche compositive dell'olio".- Proceedings of Symposium «Le centrifughe a due fasi nell'estrazione dell'olio di oliva: problematiche, prospettive qualitative e implicazioni della utilizzazione dei sottoprodotti», Accademia Nazionale dell'Olivo, Spoleto, pp. 21-41.

Montedoro, G., Servili, M., Baldioli, M., Selvaggini, R., Miniati, E. and Macchioni, A. (1993).- «Simple and hydrolyzable compounds in virgin olive oil. 3 . Spectroscopic characterizations of the secoiridoid derivatives".-J. Agric. Food Chem. 41, 2228-2234.

Norme Grassi e Derivati. Edite da Stazione Sperimentale per le Industrie degli Oli e Grassi, Milano, Methods NGD C-10 and NGD C-35 (1976).

Sweeley, C.C., Bentley, R.,. Makita, M. and Wells, W.W. (1963).— «Gas liquid chromatography of trimethylsilyl derivatives of sugars and related compounds".-J. Am. Chem. Soc. 85, 2497-2506.

Recibido: Diciembre 1997 Aceptado: Abril 1998 